\title{
The elephant at the dump: how does garbage consumption impact Asian elephants?
}

\author{
Dulmini J. Liyanage ${ }^{1,2}$ (1) Prithiviraj Fernando ${ }^{1}$ (1) $\cdot$ P. Nihal Dayawansa ${ }^{2} \cdot$ H. K. Janaka ${ }^{1}$ Jennifer Pastorini ${ }^{1,3}$ (1)
}

Received: 5 January 2021 / Accepted: 2 March 2021 / Published online: 25 March 2021

(c) The Author(s) 2021

\begin{abstract}
We studied garbage consumption by Asian elephants at the Uddakandara garbage dump in southern Sri Lanka. Garbage at the dump was classified under six categories and quantified using a grid overlay. Elephants visiting the dump were individually identified by morphological criteria and items and quantities consumed by them were determined by focal animal sampling. Dung of elephants that did not consume garbage and those from the dump were compared quantitatively and dung constituents assessed by washing through three layered sieves. A total of 17 individual elephants visited the garbage dump during the study period, all of who were males. The observed sexual bias could be related to behavioural differences between the sexes. Elephants mostly consumed 'fruits and vegetables' and 'prepared food', possibly due to their higher palatability and nutritional value. Ingestion of polythene was incidental and associated with consuming prepared food. Proportions of the six categories in elephant diet and garbage piles were significantly different, indicating that elephants were highly selective when feeding. Elephant arrivals increased in response to unloading of garbage, suggesting attraction to fresh garbage. Dung analysis found that garbage consumption did not change the quantity and constituents of dung, except for the presence of anthropogenic items. As consumed anthropogenic items were regularly excreted, retention and obstruction of the alimentary tract are unlikely in elephants. Elephants feeding on garbage had better body condition than non-garbage consuming elephants, indicating that garbage provided better nutrition than natural food and was not detrimental to their health.
\end{abstract}

Keywords Asian elephant $\cdot$ Garbage $\cdot$ Food preferences $\cdot$ Selectivity $\cdot$ Body condition $\cdot$ Dung analysis

\section{Introduction}

Garbage dumps attract many animals because they contain an abundance of food items that are high in energy and nutrients and are a reliable resource (Stringham 1989; Gilchrist and Otali 2002). A wide range of species are known to use garbage dumps, including brown bears (Ursus arctos), American black bears (Ursus americanus), polar bears (Ursus maritimus), banded mongooses (Mungos mungo),

Handling editor: Marcus Clauss.

Jennifer Pastorini

jenny@aim.uzh.ch

1 Centre for Conservation and Research, Tissamaharama, Sri Lanka

2 Department of Zoology and Environment Sciences, University of Colombo, Colombo, Sri Lanka

3 Anthropologisches Institut, Universität Zürich, Zürich, Switzerland island foxes (Urocyon littoralis clementae), wild boars (Sus scrofa), lace monitors (Varanus varius), silver gulls (Larus novaehollandiae) and yellow legged gulls (Larus michahellis) (Rogers et al. 1976; Lunn and Stirling 1985; Otali and Gilchrist 2004; Auman et al. 2008; Cahill et al. 2012; Jessop et al. 2012; Gould and Andelt 2013; Merkle et al. 2013; Peirce and Daele 2006; Steigerwald et al. 2015). Garbage feeding may have positive and negative impacts on animals, which could be direct or indirect.

Asian elephants (Elephas maximus) are "endangered" (Williams et al. 2020) and are included in Appendix I of CITES (CITES 2020). At present, elephants in Sri Lanka are largely restricted to the lowland dry zone, but still occupy $62 \%$ of the country (Fernando et al. 2021). Notably, around $70 \%$ of elephant range in Sri Lanka is in areas with resident people (Fernando et al. 2021).

Because of their body size, elephants require large quantities of food. As hindgut fermenters, they employ a strategy of feeding on low-caloric vegetation that is abundant and quickly processing large amounts of food (Clegg 2008). 
Consequently, free ranging elephants consume around $150-300 \mathrm{~kg}$ of food daily and spend about $18 \mathrm{~h}$ a day feeding (Eisenberg 1980).

Asian elephants are mega-herbivores and rely on both graze and browse. They are generalized feeders and consume more than 100 species of plants, but prefer species of the family Poaceae (grasses) and Fabaceae (legumes) (Samansiri and Weerakoon 2007). In addition to natural vegetation, elephants may consume crops by raiding (Yapa and Ratnavira 2013). Both African and Asian elephants have been reported to consume garbage (Moss 1988; Joshi 2013). Here we report on elephants feeding at a garbage dump in southern Sri Lanka.

\section{Materials and methods}

\section{Study sites}

The Uddakandara garbage dump ( $06^{\circ} 16.827^{\prime}$, E $81^{\circ}$ $20.617^{\prime}$ ) is situated in the Hambantota District in southern Sri Lanka (Fig. 1). The site is located in the dry zone, near the southwest boundary of the Yala National Park, approximately $2 \mathrm{~km}$ from the Uddakandara village. The environment around the study site consists of seasonally cultivated scrubland with sparsely distributed large trees. A compost unit is located $1.8 \mathrm{~km}$ from the garbage dump at the border of the Uddakandara village (Fig. 1). Bundala is a village approximately $13 \mathrm{~km}$ southwest of Uddakandara and lies between the Bundala National Park and the Wilmanne Sanctuary (Fig. 1). There are no open garbage dumps in the area.
Elephants range freely between the Bundala National Park and Wilmanne Sanctuary, through the Bundala area.

We obtained information on the collection and processing of garbage from employees of the Tissamaharama Pradeshiya Sabha (local administration) and compost unit. Garbage was collected from an area of approximately 100 $\mathrm{km}^{2}$ centred on Tissamaharama town, located about $6 \mathrm{~km}$ from the dump. Collected garbage originated from street markets, hotels, restaurants, shops, temples and residential areas. Half the garbage was brought to the compost unit and easily biodegradable waste and recyclable items separated. Organic waste was converted to compost, recyclable items sold and rice leftovers given to a piggery. The remaining waste was brought to the dump. The total amount of garbage collected was about 12 tons/day. As the compost unit could process only 6 tons/day, the remainder was directly dumped at the garbage disposal site. On average, five tractor loads were deposited daily in separate piles.

\section{Garbage composition}

A preliminary study was conducted at the garbage dump from 22nd to 27th of March 2018, to identify items that elephants consumed. Based on the results of it, we classified dumped garbage under six categories: 'prepared food', 'fruits and vegetables', 'leaves', 'polythene', 'paper', and 'other items' (Table 1). Data on garbage composition and feeding were collected during 21 days from April to September 2018 .

The presence of different categories of items was quantified using a $1-\mathrm{m}^{2}$ metal frame sub-divided with wires into

Fig. 1 Map of the study area

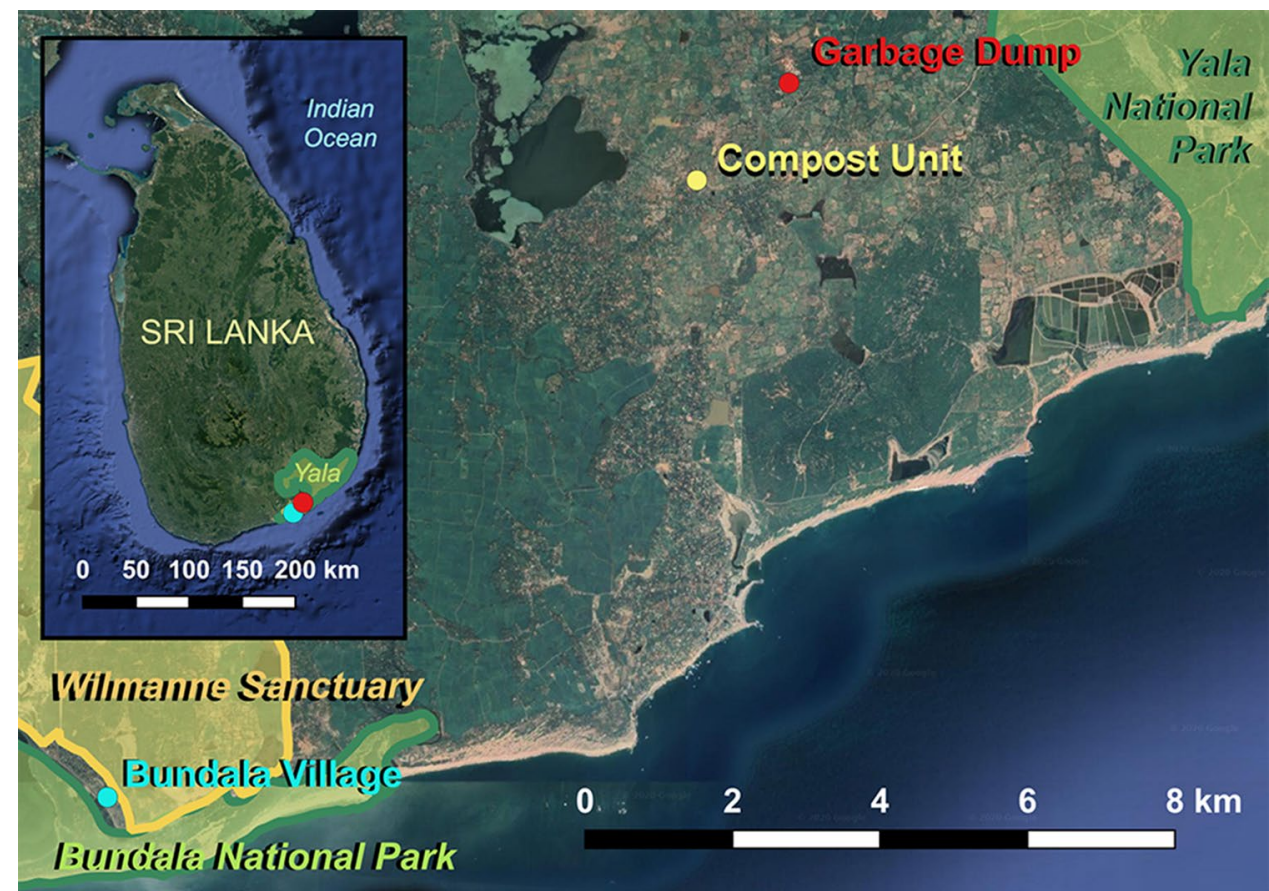


Table 1 List of items in each of the six categories of garbage at the dump

\begin{tabular}{ll}
\hline Category & Items \\
\hline Prepared food & Cooked food (e.g. rice), bakery items, flour, snacks and kitchen waste (e.g. egg shells) \\
Fruits and vegetables & Banana, watermelon, mango, papaya, pineapple, apples, oranges, jack fruit, sugarcane, corn, coconut, \\
& wood apple, breadfruit, cucumber, pumpkin, eggplant, tomatoes, potatoes, manioc, cabbage, etc \\
Leaves & Leaves from banana, coconut, manioc, leafy vegetables, paddy straw and other species of family Poaceae \\
Polythene & Lunch sheets, plastic bags, wrappers etc \\
Paper & Newspapers, tissue papers, paper \\
Other items & Garden waste, flowers, animal carcasses, cardboard, coconut husks and shells, books, clothes, pots, \\
& beverage packets, ropes, nets, wooden items, construction material, cans, bottles, cups, toys, buckets, \\
& electronics, PVC pipes, styrofoam, shoes, tyres, metal, glass, etc \\
\hline
\end{tabular}

$10 \times 10 \mathrm{~cm}$ grid cells. The grid was placed on the middle and four corners of a garbage pile and the items under each cross point were recorded under the six categories. Elephants usually began to feed on garbage as soon as it was dumped. Therefore data on garbage pile composition could only be collected after the elephants had left. Given the relative quantities of dumped garbage and that consumed by elephants, we assumed that their consumption did not significantly affect the composition of a garbage pile. In some cases, elephants remained at the garbage dump until dark, preventing garbage pile sampling. Some samples collected in early mornings were from garbage piles fed on by elephants in the previous night.

\section{Data on individual elephants}

We photographed elephants at the garbage dump and individually identified them using morphological characters of the ears (shape, folds, depigmentation and tears), tail (length, hair pattern), wounds, lumps, tushes and tusks (Vidya et al. 2014). Elephants were categorized into size classes based on approximate height and development of secondary sexual characteristics (adult $=$ shoulder height $>2.5 \mathrm{~m}$, secondary sexual characteristics prominent; sub-adult = shoulder height $2.0-2.5 \mathrm{~m}$, secondary sexual characteristics absent; juvenile $=$ shoulder height $<2.0 \mathrm{~m}$, secondary sexual characteristics absent). Height was gauged by observation. Secondary sexual characters considered were; wide trunk base, prominent nasal protuberance, deep temporal depression and large penis/ penile bulge and signs of musth (temporal discharge and urine dribbling).

The body condition of elephants was scored from March to September 2018, using a visual scale (Fernando et al. 2009). Some individuals were scored multiple times but each only once a month. Male elephants in the nearby Yala National Park that were never observed at the dump, hence assumed not to consume garbage, were scored for comparison.

\section{Elephant feeding}

We did focal animal sampling, alternating between 5-min sampling periods and intervals, from the arrival of an individual at the garbage dump till its departure. The number of mouthfuls and items ingested by elephants were recorded by direct observation using binoculars (Nikon $8 \times 40$ ). The same six categories as for the garbage composition were used to classify the items the elephants consumed.

\section{Unloading of garbage and elephant arrivals}

We recorded the times of arrival of individual elephants and tractors bringing garbage to the dump, to assess whether there was any relationship between the arrivals of elephants with unloading of garbage. The tractor could be heard approaching for around $10 \mathrm{~min}$ before reaching the garbage dump and the unloading process itself took about $10 \mathrm{~min}$. The arrival of an elephant to the garbage dump within $10 \mathrm{~min}$ before to $30 \mathrm{~min}$ after the arrival of the tractor was assumed to be in response to the unloading of garbage.

\section{Macroscopic dung analysis}

We collected fresh dung samples from elephants at the garbage dump $(n=30)$ and near Bundala $(n=33)$. The number of boli in each dung pile was noted and the circumferences of individual boli were taken using a measuring tape. The weight of the dung pile was recorded using a portable electronic balance. A single bolus from a pile was taken for further analysis.

The selected dung boli were processed using an apparatus with three stacked sieves, consisting of an upper sieve with mesh size $12.7 \mathrm{~mm}$, a middle sieve with mesh size $6.35 \mathrm{~mm}$ and a bottom sieve of cotton cloth with mesh size $0.02 \mathrm{~mm}$. Each dung sample was broken up into pieces, which were homogenized in a bucket of water. The slurry was then poured through the apparatus and washed using pressurized water so that the wash passed through the stacked sieves sequentially and fragments retained 
were sorted by size. The retained fragments on each of the sieves were collected separately, gently squeezed to remove excess water and weighed. Fragments retained in the top, middle and bottom sieves, respectively, were classified as large, medium and small. Large fragments were sorted by hand into anthropogenic and natural items. Each group was weighed separately and items observed in each category were recorded.

\section{Statistical analysis}

A Chi-squared test of homogeneity was conducted to evaluate if the different categories of garbage had the same distribution in all the garbage piles. A Tukey-Kramer test was performed for each of the six garbage categories to compare its proportion in garbage and in elephant diet. For the paired samples of elephants and the garbage piles they ate from, the Chi-squared test of homogeneity was used to compare the proportions of items the elephants consumed, with their proportions in the garbage pile. Differences in arrival times at the garbage dump, dung measurements and body condition were checked for significance with the Wilcoxon test (2-sample test, normal approximation) using JMP 13.0.0.

\section{Results}

\section{Data on individual elephants}

During the study period, 17 individual elephants were identified visiting the garbage dump, consisting of 15 adult males and 2 sub-adult males. The average number of elephants visiting the garbage dump on the 21 days was 6.4 individuals/day ( $\mathrm{SD} \pm 1.9$, range 4-9).

The mean body condition of garbage consuming elephants was $6.77 \pm 1.07$ (range $5-9, n=57$ ) and that of nongarbage consuming elephants in Yala 5.87 \pm 1.65 (range 1-8, $n=38$ ) (Wilcoxon test, $p=0.007$ ).

\section{Garbage composition}

On average, each garbage pile included $28.6 \pm 17.0 \%$ leaves, $27.8 \pm 9.7 \%$ other items, $27.2 \pm 11.2 \%$ polythene, $6.6 \pm 6.2 \%$ prepared food, $5.7 \pm 3.7 \%$ paper and $4.0 \pm 5.7 \%$ fruits and vegetables (Fig. 2). The distribution of the six categories was significantly different amongst the garbage piles (Chisquared test of homogeneity: $\chi^{2}=5536.8, p<0.05, n=41$ ). The category 'prepared food' consisted mostly of cooked rice while the 'leaves' category mainly included banana leaves.

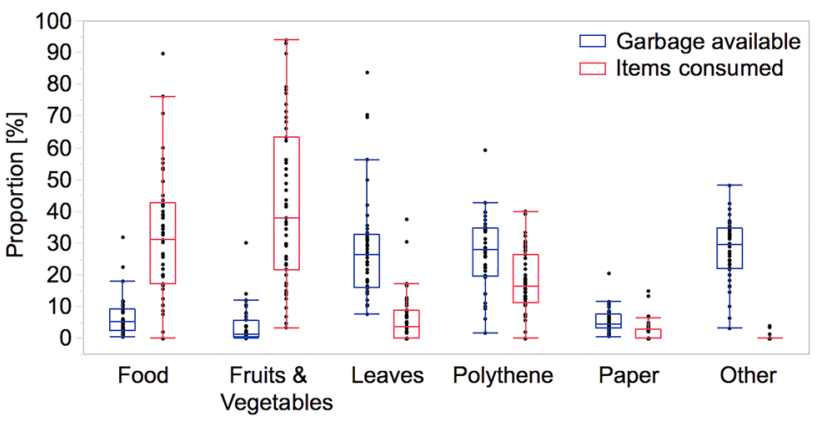

Fig. 2 Proportions of six categories of items available in the garbage piles and their proportions in the elephants' diet

\section{Elephant feeding}

Feeding data were recorded from 14 individuals over 47 visits. Data were recorded from five individuals once, two individuals twice, three individuals four times and the remaining four individuals three, five, seven and eleven times, respectively. Elephants consumed a total of 3338 mouthfuls over $2045 \mathrm{~min}$ of observation. On average, an elephant stayed at the dump for $91.1 \pm 46.8$ (range 27-194) min and consumed an average of $71.0 \pm 31.8$ mouthfuls (range $18-175$ ) per visit.

On average an elephant consumed $42.6 \pm 25.3 \%$ fruits and vegetables, $31.7 \pm 20.3 \%$ prepared food, $17.7 \pm 9.9 \%$ polythene, $6.2 \pm 8.1 \%$ leaves, $1.7 \pm 3.3 \%$ paper and $0.2 \pm 0.8 \%$ other items (Fig. 2).

Elephants consumed significantly more 'fruits and vegetables' than any other category $(p<0.001)$ and significantly more 'prepared food' than the other four categories $(p<0.001)$. 'Polythene' was consumed significantly more than 'leaves', 'paper' and 'other items' (Tukey-Kramer test, $p<0.002$, Fig. 2).

In 31 instances we collected data from a garbage pile a focal individual fed on. The composition of the six categories in the diet of elephants was significantly different from their composition in the piles they fed from (Chi-squared test of homogeneity: $\chi^{2}=33,447.0, p<0.05, \mathrm{n}=31$ ).

Elephants consumed a higher ratio of the categories 'prepared food' and 'fruits and vegetables' (Tukey-Kramer test, $p<0.05$, Fig. 2) and a lower percentage of the categories 'leaves', 'paper', 'polythene' and 'other garbage items' than present in the garbage piles (Tukey-Kramer test, $p<0.05$, Fig. 2).

\section{Unloading of garbage and elephant arrivals}

Times of arrival for 81 tractor loads and for 222 instances of elephants visiting the dump were recorded over a period of $122.3 \mathrm{~h}$ in 21 days. A total of 137 elephant arrivals occurred within the 40-min time period when garbage was unloaded, which added up to $38.1 \mathrm{~h}$ as some tractor 
arrivals overlapped. During the remaining $84.1 \mathrm{~h}$ of observation time, 85 elephant arrivals were recorded. Outside the unloading period $1.0 \pm 0.8$ elephants/h arrived at the dump and during unloading period elephant arrivals were $3.5 \pm 2.0$ elephants/h (Wilcoxon test, $p<0.001$ ).

Of the 137 elephant arrivals in response to unloading of garbage, $17(12.4 \%)$ were before (within $10 \mathrm{~min}$ ) the tractor arrived, $78(56.9 \%)$ while the tractor was unloading (10 $\mathrm{min}$ ) and $42(30.7 \%)$ after the tractor left (within $20 \mathrm{~min}$ ).

\section{Macroscopic dung analysis}

The number of boli per pile at the garbage dump was $5.6 \pm 1.4$ (range 3-10) and in Bundala 5.2 \pm 1.2 (range 3-8) (Wilcoxon test, $p=0.296$ ). Bolus circumferences at the dump were 44.0 \pm 3.7 (range 37.4-51.1 cm) and in Bundala $41.6 \pm 6.1$ (range $31.2-55.8 \mathrm{~cm}$ ) (Wilcoxon test, $p=0.094$ ). Dung piles at the garbage dump were $6.9 \pm 2.6$ (range 2.3-15.0) kg and in Bundala $4.4 \pm 1.6$ (range 1.9-7.9) kg (Wilcoxon test, $p<0.001$ ).

The 'large-natural' fragment class mostly consisted of pieces of twigs, bark, woody fragments and undigested leaves. 'Large-anthropogenic' fragments consisted of polythene, a few plastic pieces and bone fragments, and rarely artefacts such as bottle caps. The 'medium' and 'small' fragment classes were mostly residue of digested leaves. The 'small' fragment class also contained some sand and stones in samples from both locations. The proportion of large natural, medium and small sized items was not significantly different at the two locations (Table 2). Anthropogenic items were found in $24(80.0 \%)$ of the 30 dung samples from the garbage dump and in none from Bundala $(p<0.001)$.

\section{Discussion}

\section{Age and sex composition of elephants}

All elephants observed at the dump were adult or sub-adult males and no females or young were seen. Elephants have a sexually dimorphic social structure, with related females and young living in herds and males leaving the herd at puberty to lead a largely solitary life as adults (Fernando and Lande

Table 2 Percentages of different fragment sizes in the dung samples from Bundala and the garbage dump

\begin{tabular}{lccc}
\hline Fragments & Bundala & Garbage dump & $p$ (Wilcoxon test) \\
\hline Large natural & $75.7 \pm 7.9$ & $73.1 \pm 13.6$ & 0.577 \\
Large anthropogenic & $0 \pm 0$ & $3.0 \pm 4.6$ & $<0.001$ \\
Medium & $2.8 \pm 1.5$ & $3.3 \pm 1.4$ & 0.052 \\
Small & $21.5 \pm 6.7$ & $20.5 \pm 9.6$ & 0.339 \\
\hline
\end{tabular}

2000). Therefore, all the elephants at the garbage dump were males that had left their natal herds. In brown bears (Peirce and Daele 2006) and black bears (Rogers et al. 1976), the probability of males being located at garbage dumps was higher than females. Bears are solitary carnivores and males and females have separate ranges (Dahle and Swenson 2003). In contrast, no sexual bias in visits to garbage dumps was reported in species with mixed-sex groups such as banded mongoose (Gilchrist and Otali 2002) and baboons (Sapolsky and Share 2004). Therefore, the observed male bias in visits to the garbage dump is probably related to elephant social organization.

Larger home ranges, hence a higher possibility of finding garbage sources, has been suggested as a reason for the higher proportion of male bears at garbage dumps (Rogers et al. 1976). This may also be applicable to elephants as males may range over a wider area than females (Fernando et al. 2021). However, it is unlikely to explain the exclusive presence of males.

A 'despotic distribution' from avoidance of intraspecific predation and aggression by males has been suggested as an explanation for sexual bias in occurrence of bears near human settlements (Elfstrom et al. 2014). However, elephants are non-territorial and male aggression towards females or juveniles is unknown. Therefore, male avoidance is an unlikely explanation for the observed absence of females and juveniles at the garbage dump. In elephants, males tend to tolerate higher levels of human presence than herds (Fernando et al. 2021). Male elephants tend to engage in a high-risk-high-gain strategy, taking greater risks than female herds (Sukumar and Gadgil 1988; Chiyo et al. 2011). Most elephants causing conflict with humans (e.g. crop raiding) are males (Prakash et al. 2020) and in many populations, males are responsible for $70-100 \%$ of crop raiding incidents (Chiyo et al. 2012). As the studied dump was close to human dominated areas and there was human activity at the dump, elephants may have perceived it as a high-risk area, which explains the observed male bias.

\section{Garbage composition}

The distribution of the six categories of items was significantly different among garbage piles, possibly due to different loads originating from areas such as markets, residential areas and hotel zones. Therefore, elephants had a variable and wide choice of items for feeding.

'Leaves' was the commonest category in the garbage as they consisted mostly of banana leaves used as packaging material for fruits brought to market, hence entirely discarded and of a high volume. The category 'other items' was the second highest in proportion, mainly because it consisted of a large variety of items (Table 1). 'Polythene' accounted for about one-fourth of garbage as that too was used for 
wrapping and entirely discarded. Categories 'prepared food' and 'fruits and vegetables' were in low amounts, as they were only leftovers of what was used and discarded items from markets, respectively. The category 'paper' was low possibly because of its lower representation in waste from markets, restaurants and residences.

\section{Elephant diet}

Around $80 \%$ of the elephants' diet at the garbage dump consisted of organic matter and the commonest category consumed was 'fruits and vegetables'. This category overlapped with the natural food of elephants. Cultivated crops are plants that have been selectively bred by people for millennia to improve their quality, hence have higher palatability and nutritive value than natural vegetation (Santra et al. 2008; Foguekem et al. 2011). Thus, familiarity and quality may explain the high consumption of 'fruits and vegetables' by elephants at the dump.

The next commonest category ingested was 'prepared food', mostly consisting of cooked rice and bakery items. Biodegradable municipal solid waste has a high nutritional value and restaurant waste contains high levels of proteins, carbohydrates and hydrocarbons (Garcia et al. 2005). Since items in the category 'prepared food' in our study mostly originated from hotels and restaurants, they were presumably high in nutritive value and energy content. Cooked food is also very easily digested. Nutrient content is an important factor affecting the selectivity of forage by elephants (Foguekem et al. 2011). Digestibility and crude protein content are major indicators of nutritive value (Shackleton and Mentis 1992) and energy availability. In contrast, energy availability decreases with amounts of fibre and lignin content (Pehrson and Faber 1994). Natural vegetation consumed by wild elephants contains high amounts of fibre and is poor in nutritional content and energy (Santra et al. 2008; Foguekem et al. 2011). Therefore, prepared food' at the garbage dump provided elephants with more nutritious food that was higher in protein and energy than natural vegetation.

Although completely overlapping with natural vegetation, elephants consumed the category 'leaves' in relatively low amounts. This may be due to the large amount of dried out banana leaves, which probably had lower nutritive value than the normally consumed vegetation and also the availability of higher quality items at the dump.

A little less than one-fifth of consumed items consisted of polythene, mostly 'lunch sheets' $(0.02$-mm-thick polythene sheets). Polythene was ingested incidentally when edible food was enclosed in it, as for instance, cooked rice wrapped in lunch sheets. The same applied for the categories 'paper' and 'other items'. While a large number of objects were identified under the category 'other items', elephants ingested only a very small number of items in this category (Fig. 2).

\section{Food preference}

Herbivores obtain a diet with higher nutritive value by selective feeding (Field 1976). We observed a significant difference between the proportions of the six categories present in garbage and in elephants' diet. Thus, elephants were highly selective in what they ingested from the garbage dump. They showed preference for 'fruits and vegetables' and 'prepared food' and aversion to the categories 'leaves', 'paper', 'polythene' and 'other items'. Selective grazing of goats results in lower occurrence of foreign material in their rumen than in sheep (Akinrinmade and Akinrinde 2013). Elephants have a high level of sensory acuity in the trunk tip and are able to manipulate even very small items with their trunks (Rasmussen and Munger 1996). Therefore they are well equipped to sort and select items to be ingested. Selective feeding at the garbage dump was probably driven by differences in nutritive value, but may also limit ingestion of anthropogenic and harmful material by elephants.

Free ranging elephants may consume over a hundred plant species, but the majority of their diet consists of a few species and particular parts of the plants (Joshi and Singh 2008). Therefore, while elephants are generalist herbivores, their foraging is selective within the generalist framework. Factors such as food-dispersal pattern, nutrient content and toxicity influence the decision for selecting food plants by elephants (Santra et al. 2008). These same factors may help them in adapting to and selectively feeding at a 'new' resource such as a garbage dump. Selecting higher value items over those of lower worth in terms of nutrition and energy and avoidance of injurious items are consistent with the observed pattern of diet selection by elephants in consumption of garbage.

\section{Unloading of garbage and elephant arrivals}

We found that the rate of elephant arrivals was more than three times higher during unloading than the rest of the day. Unloading of garbage may attract elephants because of limited high value items and/or the degradation of items such as prepared food, vegetables and fruits with time.

From the elephants that responded to the unloading of garbage, more than half arrived while the tractor was unloading. This suggests that elephants responded to auditory cues from the tractor and perhaps also olfactory cues from the fresh garbage. A little less than a third of the elephants appeared after the unloading process was completed, indicating that they may have been further away and took longer to respond, or that they avoided human presence and activity. 


\section{Macroscopic dung analysis}

There was no difference in the number of dung boli per pile or mean bolus circumference between samples from the garbage dump and Bundala. However, the weight of a dung pile was higher at the garbage dump. As the dung at the garbage dump was collected soon after defecation and from Bundala within $12 \mathrm{~h}$ after defecation, samples from Bundala could have been more desiccated, which could explain the weight difference.

Items of anthropogenic origin, many of which were plastics, were found in $80.0 \%$ of the garbage dump dung samples. Ingesting large volumes of plastics or its retention in the stomach may reduce nutritional intake in some species (Ryan 1988). Polythene may hinder gastric fermentation, formation of fat deposits, mixing of contents, enzyme secretion and absorption of nutrients (Azzarello and Van Vleet 1987; Ryan 1988; Akinrinmade and Akinrinde 2013). Ingested plastics can also release chemicals such as polychlorinated biphenyls, leading to altered hormone levels, reproductive disorders, disease or death (Derraik 2002). Rumen impaction by plastics may cause mortality in cattle, sheep and goats (Ramaswamy and Sharma 2011; Akinrinmade and Akinrinde 2013). Blockage of the intestinal tract by plastic debris and death of small fish, seabirds, sea turtles, whales and manatees has also been reported (Derraik 2002).

The main pathology caused by ingestion of plastics is due to their retention and obstruction of the alimentary tract. We found the majority of the dung of elephants feeding at the dump to contain plastics. Therefore, free gut passage of un-digestible items including plastics appears to be the norm in elephants. Elephants are hind-gut fermenters with a simple digestive system (Clegg 2008). When foraging naturally, elephants strip off and ingest the bark and cambium of Bauhinia racemosa and Tectona grandis, or stems of banana (Musa sp.). Such material is not broken up by mastication or digestion and the entire dung pile may pass out as one intermingled fibrous mass (PF pers. obs.). The observation of indigestible items such as sand and stones in the dung of elephants also indicates the free passage of such items through the gut of elephants. Therefore, retention of ingested plastics and pathology such as impaction are unlikely to occur in elephants. Whether elephants ingesting plastics would suffer from issues such as hormonal disruption would need to be specifically investigated, which would be difficult in practice.

\section{Body condition}

Elephants that consumed garbage had higher body condition scores. As the scale was based on free ranging elephants (Fernando et al. 2009) even the higher scores observed are unlikely to indicate abnormal conditions.
Adverse health impacts of 'over-nutrition' such as obesity, cardiovascular disease, hypertension, cancer and metabolic syndrome are well documented in humans, companion animals, livestock and captive animals. However, scientific substantiation of detrimental health impacts of increased nutrition in free ranging animals is lacking (Orams 2002; Fernando et al. 2020). Ill health from over-nutrition is usually associated with co-factors such as reduced exercise, increased stress and life style changes, which maybe largely inapplicable to free ranging animals.

The higher body condition of garbage consuming elephants suggests that the garbage dump provided food that was higher in nutritional value and/or more spatially concentrated than what was available in the natural habitat. Banded mongooses (Otali and Gilchrist 2004), lace monitors (Jessop et al. 2012) and silver gulls (Auman et al. 2008) feeding on garbage and human-derived food were significantly heavier and in better body condition, compared to counterparts feeding naturally. Similarly, island foxes (Gould and Andelt 2013), polar bears (Lunn and Stirling 1985) and wild boars (Cahill et al. 2012) utilizing anthropogenic food were significantly heavier than those that did not. The body mass and condition of yellow-legged gulls decreased after the closure of a landfill (Steigerwald et al. 2015). Therefore, for a wide range of species, garbage represents a higher value food source than the natural habitat.

The garbage dump provided elephants with food that was localized, abundant and renewed daily. Therefore, elephants feeding at the dump may also expend less energy in searching for and handling of food, hence experience a more favourable cost-benefit ratio than when foraging naturally. Altmann et al. (1993) reported that female baboons that fed on garbage, expended less energy than wild-feeding females.

We observed that only some of the elephants visiting the dump were present on any given day and time. We found $20 \%$ of dung piles in the garbage dump not to contain anthropogenic material, also indicating that some elephants visited the dump only periodically. Garbage consumption also did not appear to make a significant quantitative or qualitative difference in the constituents of dung, hence the diet. Elephants, being hind-gut fermenters, have comparatively poor digestive ability compared to ruminants (Clegg 2008). Consequently their dung consists of a large amount of semi/ un-digested matter. Irrespective of the location, we found that around three quarters by weight of fragments in the dung were 'large-natural', and consisted mostly of fibrous residue of grasses, tree bark and woody fragments. Since the elephants feeding at the garbage dump did not obtain such food from the dump, they must also consume a significant amount of natural vegetation. Presumably elephants fed at the dump for only part of the time and continued to forage naturally for the major part. 
The types of food observed to be consumed by elephants and the short time spent feeding at the garbage dump suggest that their better body condition was due to consuming food of higher nutritional value. Given that body condition reflects nutrition and health status over a period of time, it also indicates that consumption of garbage did not have obvious detrimental impacts on their health.

Acknowledgements We would like to thank Sampath Ekanayaka for providing instructions on dung analysis. We are grateful to Karin Isler for advise on the statistical analysis. In addition, we thank all those who supported the study, including the workers at the garbage dump.

Funding Open Access funding provided by Universität Zürich. This study was funded by the Abraham Foundation and the University of Colombo.

\section{Compliance with ethical standards}

Conflict of interest The authors declare that there is no conflict of interest.

Open Access This article is licensed under a Creative Commons Attribution 4.0 International License, which permits use, sharing, adaptation, distribution and reproduction in any medium or format, as long as you give appropriate credit to the original author(s) and the source, provide a link to the Creative Commons licence, and indicate if changes were made. The images or other third party material in this article are included in the article's Creative Commons licence, unless indicated otherwise in a credit line to the material. If material is not included in the article's Creative Commons licence and your intended use is not permitted by statutory regulation or exceeds the permitted use, you will need to obtain permission directly from the copyright holder. To view a copy of this licence, visit http://creativecommons.org/licenses/by/4.0/.

\section{References}

Akinrinmade JF, Akinrinde AS (2013) Foreign body rumen impaction with indigestible materials in ruminants in Nigeria: a review. Bull Anim Health Prod Afr 61:629-642

Altmann J, Schoeller D, Altmann SA, Muruthi P, Sapolsky RM (1993) Body size and fatness of free-living baboons reflect food availability and activity levels. Am J Primatol 30:149-161

Auman HJ, Meathrel CE, Richardson A (2008) Supersize me: does anthropogenic food change the body condition of silver gulls? A comparison between urbanized and remote, non-urbanized areas. Waterbirds 31:122-126

Azzarello MY, Van Vleet ES (1987) Marine birds and plastic pollution. Mar Ecol Prog Ser 37:295-303

Cahill S, Llimona F, Cabañeros L, Calomardo F (2012) Characteristics of wild boar (Sus scrofa) habituation to urban areas in the Collserola Natural Park (Barcelona) and comparison with other locations. Anim Biodivers Conserv 35:221-233

Chiyo PI, Lee PC, Moss CJ, Archie EA, Hollister-Smith JA, Alberts SC (2011) No risk, no gain: effects of crop raiding and genetic diversity on body size in male elephants. Behav Ecol 22:552-558

Chiyo PI, Moss CJ, Alberts SC (2012) The influence of life history milestones and association networks on crop-raiding behavior in male African elephants. PLoS ONE 7:e31382
CITES (2020) Appendices I, II and III, valid from 28th August 2020. CITES, the Convention on International Trade in Endangered Species of Wild Fauna and Flora. https://www.cites.org/eng/app/ appendices.php. Accessed 4 Jan 2021

Clegg BW (2008) Habitat and diet selection by the African elephant at the landscape level: a functional integration of multi-scale foraging processes. Ph.D. dissertation, University of the Witwatersrand, Johannesburg, South Africa

Dahle B, Swenson J (2003) Home ranges in adult Scandinavian brown bears (Ursus arctos): effect of mass, sex, reproductive category, population density and habitat type. J Zool 260:329-335

Derraik JGB (2002) The pollution of the marine environment by plastic debris: a review. Mar Pollut Bull 44:842-852

Eisenberg JF (1980) Ecology and behavior of the Asian elephant. Elephant 1(5):36-56

Elfstrom M, Zedrosser A, Jerina K, Støen O, Kindberg J, Jonozovic M, Swenson JE (2014) Does despotic behavior or food search explain the occurrence of problem brown bears in Europe? J Wildl Manag 78:881-893

Fernando P, Lande R (2000) Molecular genetic and behavioral analysis of social organization in the Asian elephant (Elephas maximus). Behav Ecol Sociobiol 48:84-91

Fernando P, Janaka HK, Ekanayaka SKK, Nishantha HG, Pastorini J (2009) A simple method for assessing elephant body condition. Gajah 31:29-31

Fernando P, Ekanayaka SKK, Pastorini J (2020) The elephant at the fence: Almsman, panhandler, friend or foe? Eur J Wildl Res 66:e97

Fernando P, De Silva MKCR, Jayasinghe LKA, Janaka HK, Pastorini J (2021) First country-wide survey of the endangered Asian elephant: towards better conservation and management in Sri Lanka. Oryx 55:46-55

Field CR (1976) Palatability factors and nutritive vales of the food of buffaloes (Syncerus caffer) in Uganda. East Afr Wildl J 14:181-201

Foguekem D, Tchambal MN, Gonwouo LN, Ngassam P, Loomis M (2011) Nutritional status of forage plants and their use by elephant in Waza National Park, Cameroon. Sci Res Essays 6:3577-3583

Garcia AJ, Esteban MB, Marquez MC, Ramos P (2005) Biodegradable municipal solid waste: characterization and potential use as animal feedstuffs. Waste Manag 25:780-787

Gilchrist JS, Otali E (2002) The effects of refuse-feeding on homerange use, group size, and intergroup encounters in the banded mongoose. Can J Zool 80:1795-1802

Gould NP, Andelt WF (2013) Effect of anthropogenically developed areas on spatial distribution of island foxes. J Mammal 94:662-671

Jessop TS, Smissen P, Scheelings F, Dempster T (2012) Demographic and phenotypic effects of human mediated trophic subsidy on a large Australian lizard (Varanus varius): meal ticket or last supper? PLoS ONE 7(4):e34069

Joshi R (2013) Evaluating the impact of human activities during the Maha-Kumbh 2010 fair on elephants in the Shivalik Elephant Reserve. Trop Nat Hist 13:107-129

Joshi R, Singh R (2008) Feeding behaviour of wild Asian elephants (Elephas maximus) in the Rajaji National Park. J Am Sci 4(2):34-48

Lunn NJ, Stirling I (1985) The significance of supplemental food to polar bears during the ice-free period of Hudson Bay. Can J Zool 63:2291-2297

Merkle JA, Robinson HS, Krausman PR, Alaback P (2013) Food availability and foraging near human developments by black bears. J Mammal 94:378-385

Moss CJ (1988) Elephant memories: thirteen years in the life of an elephant family. William Morrow, New York 
Orams MB (2002) Feeding wildlife as a tourism attraction: a review of issues and impacts. Tour Manag 23:281-293

Otali E, Gilchrist JS (2004) The effects of refuse feeding on body condition, reproduction, and survival of banded mongooses. J Mammal 85:491-497

Pehrson A, Faber WE (1994) Individual variation of in vitro dry matter digestibility in moose. J Range Manag 47:392-394

Peirce KN, Daele LJV (2006) Use of a garbage dump by brown bears in Dillingham, Alaska. Ursus 17:165-177

Prakash TGSL, Wijeratne AW, Fernando P (2020) Human-elephant conflict in Sri Lanka: patterns and extent. Gajah 51:16-25

Ramaswamy V, Sharma HR (2011) Plastic bags-threat to environment and cattle health: a retrospective study from Gondar city of Ethiopia. IIOAB J 2:7-12

Rasmussen LEL, Munger BL (1996) The sensorineural specializations of the trunk tip (finger) of the Asian Elephant, Elephas maximus. Anat Rec 246:127-134

Rogers LL, Kuen DW, Erickson AW, Harger EM, Verme LJ, Ozoga JJ (1976) Characteristics and management of black bears that feed in garbage dumps, campgrounds or residential areas. Bears: their biology and management, vol 3. IUCN Publications, Binghamton, pp 169-175

Ryan PG (1988) Effects of ingested plastic on seabird feeding: Evidence from chickens. Mar Pollut Bull 19:125-128

Samansiri KAP, Weerakoon DK (2007) Feeding behaviour of Asian elephants in the Northwestern region of Sri Lanka. Gajah 27:27-34

Santra AK, Pan S, Samanta AK, Das S, Halder S (2008) Nutritional status of forage plants and their use by wild elephants in South West Bengal, India. Trop Ecol 49:251-257

Sapolsky RM, Share LJ (2004) A pacific culture among wild baboons: its emergence and transmission. PLoS Biol 2:535-541
Shackleton CM, Mentis MT (1992) Seasonal changes in nutrient content under three defoliation treatments in two coastal grassland communities of Transkei. J Grassl Soc South Afr 9:30-37

Steigerwald EC, Igual J, Payo-Payo A, Tavecchia G (2015) Effects of decreased anthropogenic food availability on an opportunistic gull: evidence for a size-mediated response in breeding females. Ibis 157:439-448

Stringham SF (1989) Demographic consequences of bears eating garbage at dumps: an overview. In: Bromley M (ed) Bear-people conflicts: proceedings of a symposium on management strategies. Northwest Territories Department of Renewable Resources, Yellowknife, pp 35-42

Sukumar R, Gadgil M (1988) Male-female differences in foraging on crops by Asian elephants. Anim Behav 36:1233-1235

Vidya TNC, Prasad D, Ghosh A (2014) Individual identification in Asian elephants. Gajah 40:3-17

Williams C, Tiwari SK, Goswami VR, de Silva S, Kumar A, Baskaran N, Yoganand K, Menon V (2020) Elephas maximus. IUCN Red List of Threatened Species. https://doi.org/10.2305/IUCN.UK. 2020-3.RLTS.T7140A45818198.en

Yapa A, Ratnavira G (2013) Order Proboscidea-elephants. The mammals of Sri Lanka. Field Ornithology Group of Sri Lanka, Colombo, pp 79-117

Publisher's Note Springer Nature remains neutral with regard to jurisdictional claims in published maps and institutional affiliations. 